\title{
Ecological and genetical survey on two deep-sea holothurians: Benthogone rosea and Benthodytes typica*
}

\author{
Paolo Maria Bisol ${ }^{1}$, Rodolfo Costa ${ }^{1}$ and Myriam Sibuet ${ }^{2}$ \\ ${ }^{1}$ Instituto di Biologia Animale, Università di Padova, Via Loredan n. 10, I-35100 Padova, Italy \\ ${ }^{2}$ Centre Océanologique de Bretagne, CNEXO, 29 N Plouzané, France
}

\begin{abstract}
Ecological, biological and genetical features of 2 populations of deep-sea holothurians have been studied. The 2 species concerned, Benthogone rosea Koehler and Benthodytes typica Theel belong to the strictly abyssal order Elasipoda. In the 2 collection areas they represent the dominant species of the megafauna. Trophic resources and other environmental characteristics are quite similar at the 2 sampling sites. Trawl captures and bottom photographic surveys suggest the presence of large populations. Results of genetic studies provide the first published estimates of very low levels of genetic polymorphism in populations of strictly abyssal species.
\end{abstract}

\section{INTRODUCTION}

Ecological and biological features of the deep-sea have received attention in a number of studies which have analysed organismic diversity, distribution, reproductive patterns and trophic behaviour, aiming at a better understanding of adaptive mechanisms (Hessler and Sanders, 1967; Sanders and Grassle, 1971; Dayton and Hessler, 1972; Rokop, 1974; Grassle and Grassle, 1978; Monniot, 1979; Sibuet, 1977, 1980; Rex, 1981). The influence of high pressure and low temperature in connection with limited food availability, the stability of trophic resources and the hypothesis of time stability, have also been considered (Sanders, 1969; Siebenaller and Somero, 1978; Valentine and Ayala, 1978). As the genetic structure of a population is largely responsible for its morphological, physiological and behavioural characteristics (Ayala and Valentine, 1978), genetic analysis can be an important tool for the study of deep-sea populations. A valuable approach to genetic analysis is offered by electrophoretical techniques by which the distribution of enzyme polymorphisms can be examined and the

\footnotetext{
- Contribution No. 826 du Centre Océanologique de Bretagne. Supported in part by the Italian MPI grant N. 120124
}

genetic variability of the populations be estimated, even though only a limited sample of the whole genome can be analysed.

Measures of genetic variability are available for many organisms from ecologically different environments (Nevo, 1978). Nevertheless, comparatively few data concerning deep-sea species have been produced (Doyle, 1972; Gooch and Schopf, 1972; Ayala and Valentine, 1974; Ayala et al., 1975; Valentine and Ayala, 1975; Murphy et al., 1976; Costa and Bisol, 1978; Siebenaller, 1978).

Echinoderms constitute a well represented phylum among marine invertebrates in the deep-sea. They comprise species, families, or even orders, restricted to great depths and have been the most widely studied deep-sea organisms. However, the data published to date refer mainly to species of the classes Asteroidea and Ophiuroidea which are not strictly abyssal.

Here we report data concerning 2 species, Benthogone rosea Koehler (Laetmogonidae) and Benthodytes typica Theel (Psychropotidae), which belong to the strictly abyssal order Elasipoda (Holothuroidea) and are particularly abundant in the 2 deep-sea basins considered: the Bay of Biscay and the Demerara plain. Information about their behaviour, distribution, environmental conditions and genetic variability was 
obtained in a French research program on the ecology of the deep-sea.

\section{MATERIALS AND METHODS}

The holothurians studied were taken from 2 deepsea stations during the 'Biogas' cruise (Laubier and Sibuet, 1979) and the 'Demeraby' cruise (Sibuet et al., 1982), organized by CNEXO-COB. Several trawls produced a large number of individuals of Benthogone rosea in the Bay of Biscay (Meriadzeck Plateau, Station $1,47^{\circ}, 32^{\prime} \mathrm{N}, 08^{\circ} 30^{\prime} \mathrm{W} ; 2,100 \mathrm{~m}$ depth) and Benthodytes typica in the Demerara abyssal plain $\left(8^{\circ} 09^{\prime} \mathrm{N}\right.$, $49^{\circ} 04^{\prime} \mathrm{W} ; 4,150 \mathrm{~m}$ depth); 51 specimens of $B$. rosea (Trawls CP 33 and $C P 34$ ) and 86 specimens of $B$. typica (CPO1, CPO2, CPO3; 28, 34, 24 individuals respectively) were quickly frozen and kept in the freezer until electrophoresis. Other specimens collected in considerable quantity at the same stations were measured, dissected for anatomic observations, and kept in alcohol. For B. rosea, tissue samples from the digestive tube (different parts: oral, intermediate, anal), gonads, and longitudinal muscle bands were first analysed separately to check the tissue specificity of the enzymes. Since no overlapping zones were observed, the tissues were subsequently mixed and homogenized. Samples were homogenized in $300 \mu \mathrm{l}$ of $0.01 \mathrm{M}$ Tris- $\mathrm{HCl}$ buffer, $\mathrm{pH} 7.5$, containing $0.3 \mathrm{mg}$ $\mathrm{ml}^{-1} \mathrm{NADP}$.

The homogenates were centrifuged at 6,000 rpm for $15 \mathrm{~min}$ at $0^{\circ} \mathrm{C}$. Electrophoretic analyses were performed on horizontal starch gel according to Selander et al. $\left(19^{r} ; 1\right)$. The following gel-electrode buffer systems were used: (A) Tris-EDTA-boric acid, pH 9.1; (B) Tris-boric acid, $\mathrm{pH} 8.5$; (C) Tris-citric acid, $\mathrm{pH} 7.0$; (D) Lithium hydroxid boric acid, pH 8.2. Table 1 lists the enzymes assayed, the abbreviations used to designate the enzymes, the buffer systems used for the runs, and the staining steps.

\section{RESULTS}

\section{Environmental characteristics}

General information about the topography, bottom currents, bottom temperatures and sediment characteristics at the two stations is summarized in Table 2.

The 2 deep-sea areas are located in the eastern and western parts of the North Atlantic Ocean (Fig. 1), 200 and 270 miles, respectively, from the continental landmass, at different depths. Both have a smooth slope, suffer a possibly similar influence from the continent as they are near the continental slope and have a relatively heavy sedimentation rate. Granulometric analysis indicates a dominance of the fine grained fraction $(<63 \mu \mathrm{m})$.

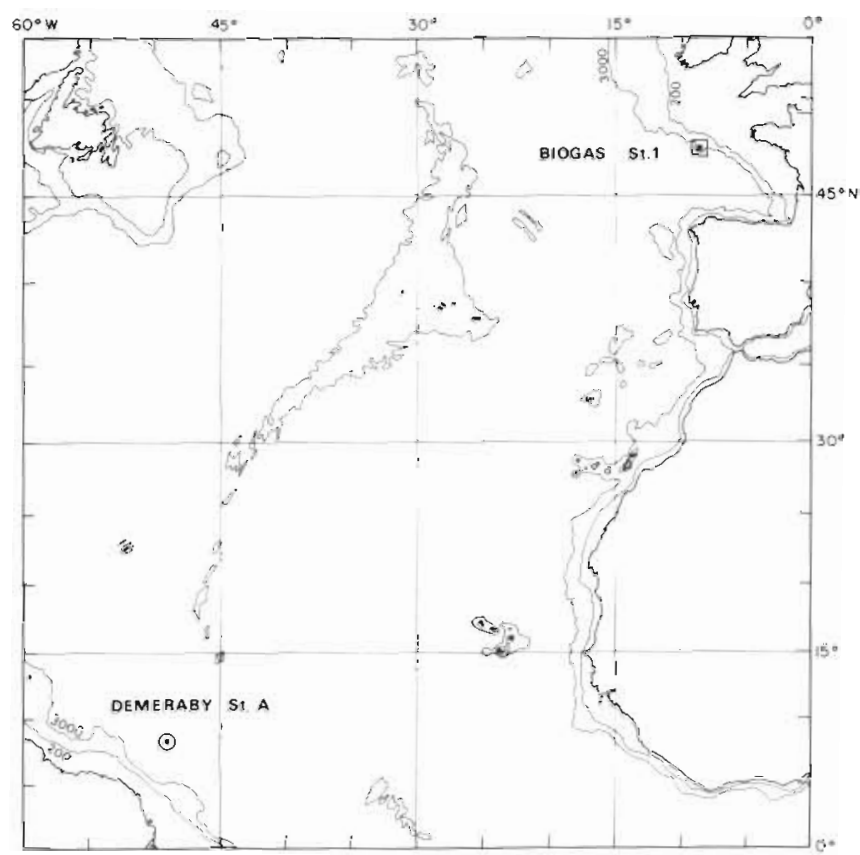

Fig. 1. Location of sampling stations

Table 1. Benthogone rosea and Benthodytes typica. Enzymes assayed and buffer systems used in the study of genetic variation

\begin{tabular}{|c|c|c|c|c|}
\hline Enzyme & Abbreviation & $\begin{array}{c}\text { Gel and } \\
\text { electrode buffer }\end{array}$ & Staining buffer & $\mathrm{pH}$ \\
\hline Acid phosphatase & Acph & C & Tris-Maleate-NaOH & 5.0 \\
\hline Alkaline phosphatase & Aph & B & Tris- $\mathrm{HCl}$ & 9.0 \\
\hline Amylase & Amy & $\mathrm{C}$ & Mono and bibasic phosphate & 6.5 \\
\hline Aminopeptidase & Ap & $\mathrm{B}$ & Tris- $\mathrm{HCl}$ & 7.4 \\
\hline Esterase & Est & A & Mono and bibasic phosphate & 6.5 \\
\hline Esterase D & Est-D & $A$ & Mono and bibasic phosphate & 6.5 \\
\hline Glutamatedehydrogenase & Gdh & $\mathrm{C}$ & Tris- $\mathrm{HCl}$ & 7.8 \\
\hline Leucineaminopeptidase & Lap & $D$ & Tris-Maleate-NaOH & 6.0 \\
\hline Mannosephosphateisomerase & Mpi & $\mathrm{B}$ & Tris-HCl & 8.0 \\
\hline Glucosephosphateisomerase & Gpi & $\mathrm{B}$ & Tris-HCl & 8.0 \\
\hline Superoxidedismutase & Sod & $\mathrm{B}$ & Tris- $\mathrm{HCl}$ & 8.5 \\
\hline
\end{tabular}


Table 2. Environmental characteristics of the 2 deep sea stations

\begin{tabular}{|c|c|c|}
\hline & $\begin{array}{c}\text { Bay of Biscay } \\
\text { (Meriadzek plateau) }\end{array}$ & Demerara Basin \\
\hline Depth $(\mathrm{m})$ & 2100 & 4440 \\
\hline Slope $(\%)$ & 1.2 & 0.2 \\
\hline Bottom temperature $\left({ }^{\circ} \mathrm{C}\right)$ & 2.5 & 2.2 \\
\hline Deep current max. $\left(\mathrm{cm} \mathrm{s}^{-1}\right)$ & 20 & 17 \\
\hline Sedimentation rate $\left(\mathrm{cm} 10^{-3} \mathrm{yr}\right)$ & 2 & 1.8 \\
\hline \multicolumn{3}{|l|}{ Sediment characteristics } \\
\hline$\%$ of coarse grained sediment fraction $(>63 \mu \mathrm{m})$ & 10 & 1.8 \\
\hline$\% \mathrm{CaCO}_{3}$ & 53 & 11 \\
\hline$\%$ Org. C & $0,38 \quad(\sigma=0.038)$ & $0,60(\sigma=0.057)$ \\
\hline$\%$ Tot. N & $0,067(\sigma=0.006)$ & $0,95(\sigma=0.0010)$ \\
\hline \multicolumn{3}{|l|}{ Fauna characteristics } \\
\hline $\begin{array}{l}\text { Density of holothurians } N^{\circ} \text { of individuals } \\
\left(\mathrm{m}^{-2} \times 10^{-4}\right) \text { (photographic estimate) }\end{array}$ & 150 & 90 \\
\hline Number of holothurian species & 15 & 9 \\
\hline
\end{tabular}

The trophic resources in the 2 areas also seem to be similar, as equal amounts of $\mathrm{NaOH}$ soluble proteins (thought to be easily assimilated by the animals) are detectable in the organic matter of the sediment. The values for such proteins are, respectively, $0.64 \mathrm{mg} \mathrm{g}^{-1}$ and $0.61 \mathrm{mg} \mathrm{g}^{-1}$ in the Bay of Biscay and in the Demerara basin near the base of the large sedimentary cone of the Amazonia.

\section{Biology of the two species}

\section{Benthogone rosea Koehler}

According to Hansen (1975), Benthogone rosea is distributed mainly in the North East Atlantic from Ireland to Cape Verde Island. Only 3 other specimens have been found along the East African coast and near New Zealand. The depth range, 1,105 to 2,480 m, appears to be relatively restricted for a deep-sea holothurian. The intensive sampling program of the 'Biogas' cruises confirmed the limits of distribution of this species which was found only at Station $1(1,800$ to $2,250 \mathrm{~m}$ ) and was present in all 18 trawls carried out at that station. In total 610 individuals were collected. The density estimated from trawl captures and from photographic survey in a prospected area of $52,200 \mathrm{~m}^{2}$ is 75 ind per $10^{4} \mathrm{~m}^{2}$ (trawl estimate) and 150 ind per $10^{4} \mathrm{~m}^{2}$ (photographic estimate) (Sibuet and Lawrence, 1981). Distribution in aggregates is strongly suggested by the variation in the number of specimens collected by trawls (ranging from 1 to 132 trawl $^{-1}$ ) or seen in a series of photographs.

Distributions of size frequencies of individuals collected in 5 trawls are presented in Fig. 2. The unimodal curves suggest the existence of a single population.

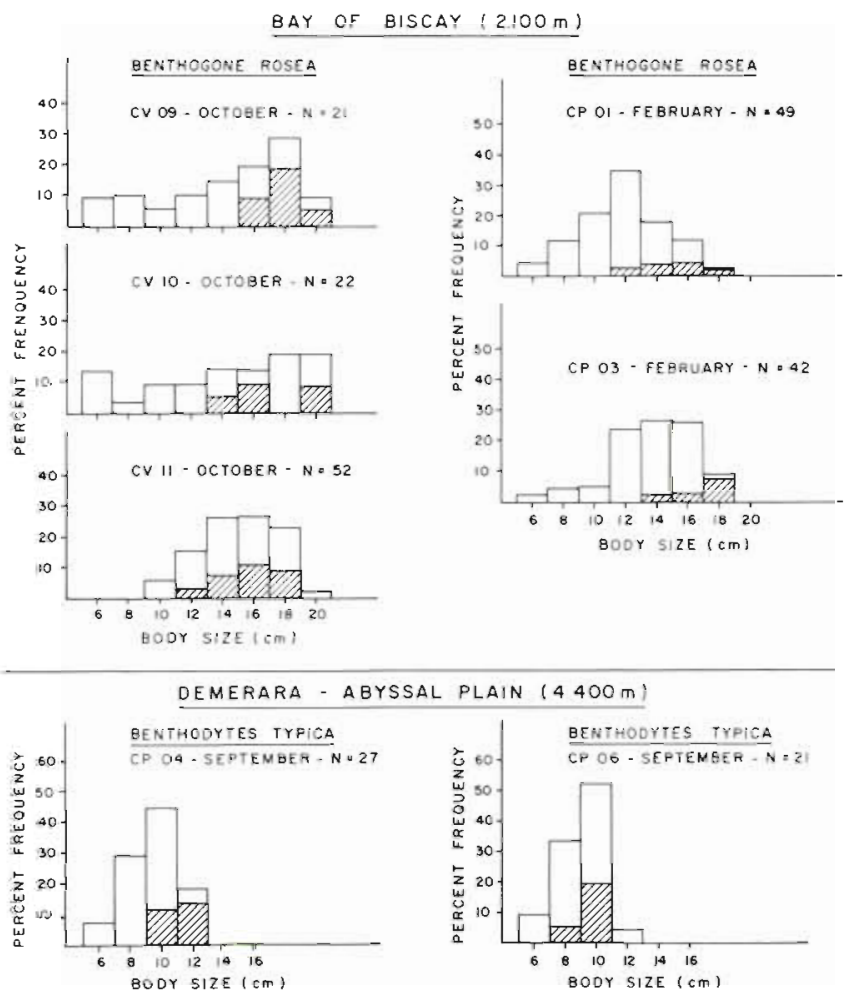

Fig. 2. Distribution of size frequencies of individuals collected in 2 sampling areas

The reproductive pattern of Benthogone rosea is not known. We have made some preliminary observations on the distribution of immature and mature specimens (some of the latter including individuals carrying large visible eggs) in samples collected at the same station during 3 different cruises made in different seasons.

Recent literature has highlighted reproductive periodicity in the deep sea from studies on 
echinoderms (ophiuroids) living at a depth of about 2,000 m (Tyler and Gage, 1979).

Synchronous year-round reproduction was suggested for abyssal species by Rokop (1974). The present observations on deep-sea holothurians whose reproductive strategies have never been studied indicate the presence of several stages of gonad development and ripe gonads with large eggs in each distinct season but do not allow us to deduce the rhythm of spawning.

Benthogone rosea is sedentary; it crawls on the sediment surface, its digestive tube always full of mud. Selection and assimilation of organic compounds from sediment have been studied by Khripounoff and Sibuet (1980) and Sibuet et al. (1982); the results revealed the metabolic relevance of the proteins which were highly selected and assimilated.

\section{Benthodytes typica Theel}

Benthodytes typica is regarded as a cosmopolitan (Hansen, 1975). However, the specimens collected to date came mainly from the western part of the North Atlantic Ocean. In addition, a few specimens have been found outside that area. Individuals of $B$. typica have been collected at depths ranging from 1,873 to $4,700 \mathrm{~m}$, as well as from 315 to $1,401 \mathrm{~m}$, near New England.

During the 'Demeraby' cruise, 268 Benthodytes typica were collected in the 6 trawls performed at Station A, covering an area of about $43,000 \mathrm{~m}^{2}$. This was probably one of the first times in which such a large number of individuals had been collected in one area at more than $4,000 \mathrm{~m}$.

This concentration suggests the presence of a particularly large population in the Station-A area. In fact, at another station prospected during the same cruise (Station B, 190 miles away from Station A), only 3 specimens of this species were collected at 4,800 m.

The density of the population at Station $\mathrm{A}$, estimated from trawl captures, is 62 per $10^{4} \mathrm{~m}^{2}$ with a relatively homogeneous spatial distribution as suggested by the low variation among the 6 captures (minimum 45 , maximum 100 specimens) and from a photographic survey of $800 \mathrm{~m}^{2}$ which showed regularly 1 or 2 individuals $100 \mathrm{~m}^{-2}$.

Specimens from 2 trawls were measured and dissected. The normal distribution of the curves (Fig. 2) and the mean size of $9 \mathrm{~cm}$ in both samples, suggest that all specimens belong to the same population.

The analysis of sexually mature individuals revealed the same sex ratio in each group of holothurians $(43 \%$ females $/ 56 \%$ males). About $20 \%$ of the specimens carried distinct white eggs. Like Benthogone rosea, Benthodytes typica lives on muddy sediments and accumulates mud in its digestive tube. However, the thinness of the tegument and the fragility of the intestine made more detailed examination of the gut content impossible.

\section{Genetic variability}

Of Benthogone rosea 51 specimens were assayed for 8 gene-enzyme systems and 13 loci were detected. Table 3 lists the loci and gives, for each locus, sample size, allelic frequencies and frequency of heterozygotes. The results from the 2 trawls have been pooled since the allele distributions were statistically homogeneous. The locus with the least anodal migration and, for each locus, the allele with the least anodal migration, are designated as 1 and a, respectively. The polymorphic loci showed patterns in agreement with

Table 3. Benthogone rosea. Allelic frequencies at 13 loci in a natural population. ( $N$ is number of genes sampled at each locus)

\begin{tabular}{|c|c|c|c|c|c|c|}
\hline \multirow[t]{2}{*}{ Locus } & \multirow[t]{2}{*}{$\mathrm{N}$} & \multicolumn{3}{|c|}{ Allelic frequencies } & \multicolumn{2}{|c|}{ Frequency of heterozygotes } \\
\hline & & a & $b$ & $b$ & observed & expected \\
\hline Acph-1 & 80 & 1 & - & - & 0.0 & 0.0 \\
\hline Aph-1 & 86 & 1 & - & - & 0.0 & 0.0 \\
\hline$A p-2$ & 90 & 0.989 & 0.011 & - & 0.022 & 0.022 \\
\hline $\mathrm{Ap}-4$ & 90 & 1 & - & - & 0.0 & 0.0 \\
\hline Est-3 & 86 & 1 & - & - & 0.0 & 0.0 \\
\hline Est-4 & 102 & 0.020 & 0.970 & 0.010 & 0.059 & 0.057 \\
\hline Est-5 & 102 & 1 & - & - & 0.0 & 0.0 \\
\hline Est-D & 86 & 1 & - & - & 0.0 & 0.0 \\
\hline Lap-1 & 14 & 1 & - & - & 0.0 & 0.0 \\
\hline Lap-2 & 22 & 0.955 & 0.045 & - & 0.091 & 0.087 \\
\hline Lap-3 & 72 & 0.986 & 0.014 & - & 0.028 & 0.027 \\
\hline Gpi-1 & 92 & 0.957 & 0.043 & - & 0.087 & 0.083 \\
\hline Sod-1 & 80 & 0.975 & 0.025 & - & 0.050 & 0.049 \\
\hline
\end{tabular}


Table 4. Benthodytes typica. Allelic frequencies at 14 loci in a natural population. ( $N$ is number of genes sampled at each locus)

\begin{tabular}{|c|c|c|c|c|c|}
\hline \multirow[t]{2}{*}{ Locus } & \multirow[t]{2}{*}{$N$} & \multicolumn{2}{|c|}{ Allelic frequencies } & \multicolumn{2}{|c|}{ Frequency of heterozygotes } \\
\hline & & $a$ & $b$ & observed & expected \\
\hline Acph-1 & 118 & 0.025 & 0.975 & 0.051 & 0.050 \\
\hline Amy-1 & 140 & 1 & - & 0.0 & 0.0 \\
\hline Ap-1 & 110 & 1 & - & 0.0 & 0.0 \\
\hline Ap- 2 & 142 & 1 & - & 0.0 & 0.0 \\
\hline Aph-1 & 60 & 1 & - & 0.0 & 0.0 \\
\hline Aph-2 & 38 & 1 & - & 0.0 & 0.0 \\
\hline Est -1 & 172 & 1 & - & 0.0 & 0.0 \\
\hline Est-D & 172 & 0.006 & 0.994 & 0.012 & 0.012 \\
\hline Gdh-1 & 72 & 0.986 & 0.014 & 0.028 & 0.027 \\
\hline Lap-1 & 96 & 1 & - & 0.0 & 0.0 \\
\hline Lap-2 & 84 & 1 & - & 0.0 & 0.0 \\
\hline Mpi-1 & 122 & 1 & - & 0.0 & 0.0 \\
\hline Gpi-1 & 102 & 0.882 & 0.118 & 0.157 & 0.208 \\
\hline Sod-1 & 122 & 0.025 & 0.975 & 0.049 & 0.048 \\
\hline
\end{tabular}

the expectations of mendelian heredity and the HardyWeinberg principle. For all the variable loci, the most common allele has a frequency higher than 0.95, Lap-2 being the most polymorphic locus with about $9 \%$ heterozygotes. The survey of enzyme variability in Benthodytes typica was performed on a larger sample of specimens and on more enzymes; 11 enzymes were analyzed in a total of 86 specimens. The results from the 3 trawls, also pooled since the allele distributions were statistically homogeneous, are given in Table 4. For each locus the observed genotypic patterns are in agreement with Hardy-Weinberg expectations. Moreover, the distribution of allele frequencies is very similar to that found in Benthogone rosea: at all polymorphic loci the most common allele has frequencies very near to, or higher than, 0.90 .

The level of genetic polymorphism in the populations of 2 species examined appears low, as summarized in Table 5.

\section{DISCUSSION AND CONCLUSION}

The 2 species studied, Benthogone rosea and Benthodytes typica, belong to the same deep-sea order Elasipoda. In the 2 collection areas they are the dominant species of the megafauna (Sibuet, unpubl.). The large size of the populations and the presence of mature gonads, sometimes with large eggs, testify to their adaptation to the deep-sea environment, which is quite similar in terms of trophic resources at the 2 sampling sites. Both areas are characterized by the presence, in the sediment, of comparable levels of organic matter (\% of $\mathrm{NaOH}$ soluble proteins) which is a major food resource for these limivorous sedentary organisms (Khripounoff and Sibuet, 1980; Sibuet et al., 1982); and by relatively homogeneous environmental conditions without any morphological or trophic barrier. This similarity in the ecological and biological factors characterizing the 2 holothurians is paralleled by very similar, low levels of genetic variability. Several fac-

Table 5. Benthogone rosea and Benthodytes typica. Summary of genetic variability

\begin{tabular}{|c|c|c|}
\hline & Benthogone rosea & Benthodytes typica \\
\hline Number of loci & 13 & 14 \\
\hline Number of individuals & 51 & 86 \\
\hline Genes sampled per locus & $77.077 \pm 7.63$ & $110.714 \pm 10.488$ \\
\hline Alleles per locus & $1.538 \pm 0.18$ & $1.357 \pm 0.133$ \\
\hline Polymorphic loci" & 0.461 & 0.357 \\
\hline$\cdots$ & 0.0 & 0.071 \\
\hline \multicolumn{3}{|l|}{ Frequency of heterozygotes } \\
\hline Observed & $0.026 \pm 0.01$ & $0.021 \pm$ \\
\hline Expected & $0.025 \pm 0.01$ & $0.025 \pm$ \\
\hline
\end{tabular}

A locus is considered polymorphic when the frequency $(\mathrm{P})$ of the most cornmon allele is $\bullet P \leq 0.99 ; \cdots P \leq 0.95$ 
tors could account for the observed low degree of heterozygosity. Low genetic variability could be the result of genetic drift but the data concerning the population sizes seem to rule out this possibility.

The homogeneous distribution of the allele frequency among samples collected in different trawls, as well as the normal distribution of size frequencies of specimens, points to the large size and the singleness of the populations studied. Alternatively, the low genetic variability could be due to selective phenomena which favour homozygotes. The 2 species studied can be considered as highly specialized, given the rigourous and stable conditions of their environment. High hydrostatic pressure and low temperature could significantly affect the conservative constraints of the enzyme molecular structures.

Evidence that hydrostatic pressure and temperature exert relevant influences on structure and kinetics of enzymes, and consequently on the physiological processes they control, has been produced by Hochachka (1975), Somero and Hochachka (1976a, b) and Somero (1979). In particular, pressure has been shown to affect the biochemical reactions which imply volume changes (Johnson and Eyring, 1970; Low and Somero, 1975a,b,c; Somero and Hochachka, 1976a). The data reported here on holothuroids represent the first indication of very low genetic polymorphism in populations of strictly abyssal species. Previous studies on the genetic structure of deep-sea echinoderms belonging to the classes Asteroidea (Astropectinidae, Benthopectinidae, Zoroasteridae) and Ophiuroidea (Ophiolepidae), reported a high degree of polymorphism (see the literature cited in 'Introduction').

Those echinoderms are relatively cosmopolitan with a diet not well identified, even if the gut content and morphological structure suggest an omnivorous tendency with a trend toward a detritivorous one. However, it is difficult to understand how differences in nutritional behaviour could account for the differences in the level of genetic variability observed. Our data suggest that even in deep-sea habitats different degrees of polymorphism exist. Different levels of genetic variability could reflect different levels of specialization of the species and, if operating, different adaptive strategies. Finally, we would like to mention a factor that may be of great importance in considering the processes of colonization and adaptation in the deep-sea. The abyssal benthic environment is generally characterized by stable physical features with hardly any noticeable seasonal changes (Menzies et al., 1973). Nevertheless, it cannot be considered uniform, as many sources of heterogeneity and a high degree of microhabitat specialization have also been suggested (Jumars, 1976; Rex, 1981; Jumars and Gallagher, 1982)
If the deep-sea ecosystem is beginning to become affected by human activities (exploitation, waste dumping, storage, deep-sea mining), implications of ecology and evolution will be important. The sensibility to changes in environmental conditions requires more knowledge about adaptation and genetic structure of deep-sea populations.

\section{LITERATURE CITED}

Ayala, F. J., Valentine, J. W. (1974). Genetic variability in the cosmopolitan deep-water ophiuran Ophiomusium lymani. Mar. Biol. 27: 51-57

Ayala, F. J., Valentine, J W. (1978). Genetic variation and resource stability in marine invertebrates. In: Battaglia, B., Beardmore, J. A. (ed.) Marine organisms. Genetics, ecology and evolution. Plenum Press, New York, p. 23-51

Ayala, F. J., Valentine, J. W., Hedgecock, D., Barr, L. G. (1975). Deep-sea Asteroids: high genetic variability in a stable environment. Evolution 29: 203-212

Costa, R., Bisol, P. M. (1978). Genetic variability in deep-sea organisms. Biol. Bull. mar. biol. Lab., Woods Hole 155: 125-133

Dayton, P. K., Hessler, R. R. (1972). Role of biological disturbance in maintaining diversity in the deep-sea. Deep Sea Res. 19: 199-208

Doyle, R. W (1972). Genetic variation in Ophiomusium lymani (Echinodermata) populations in the deep-sea. Deep Sea Res. 19: 661-664

Grassle, Y. F., Grassle, J. P. (1978). Life histories and genetic variation in marine invertebrates. In: Battaglia, B., Beardmore, J. A. (ed.) Marine organisms. Genetics, ecology and evolution. Plenum Press, New York, p. 347-364

Gooch, J. C., Schopf, T. J. M. (1972). Genetic variability in the deep sea: relation to environmental variability. Evolution 26: $545-552$

Hansen, B. (1975). Systematics and biology of the deep-sea Holothurians. Part. 1 Elasipoda. Galathea report 13: 262

Hessler, R. R., Sanders, H. L. (1967). Faunal diversity in the deep-sea. Deep Sea Res. 14:65-78

Hochachka, P. W. (ed.) (1975). Pressure effects on biochemical systems of abyssal and midwater organisms: the 1973 Kona Expedition of the alpha helix. Comp. Biochem. Physiol, B 52: 1-199

Johnson, F. H., Eyring, H. (1970). The kinetic basis of pressure effects in biology and chemistry. In: Zimmerman. A. M (ed.) High pressure effects on cellular processes. Academic Press, New York, p. 1-44

Jumars, P. A. (1976). Deep-sea species diversity: does it have a characteristic scale? J. mar. Res. 34: 217-246

Jumars, P. A., Gallagher, E. D. (1982). Deep-sea community structure: three plays on the benthic proscenium. In: Ernst, W. G., Morin, J. G. (ed.) The environment of the deep sea. Prentice Hall, New Jersey, p. 371

Khripounoff, A., Sibuet, M. (1980). La nutrition d'échinodermes abyssaux. I-Alimentation des holothuries. Mar. Biol. 60: 17-26

Laubier, L., Sibuet, M. (1979). Ecology of the benthic communities of the deep North East Atlantic. Ambio Spec. Rep. $6: 37-42$

Low, P. S., Somero, G. N. (1975a). Activation volumes in enzymic catalysis: their sources and modification by lowmolecular-weight solutes. Proc. natn. Acad. Sci. U.S.A. 72: $3014-3018$ 
Low, P. S., Somero, G. N. (1975b). Protein hydration changes during catalysis: a new mechanism of enzymic rateenhancement and jon activation/inhibition of catalysis. Proc. natn. Acad. Sci. U.S.A. 72: 3305-3309

Low, P. S., Somero, G. N. (1975c). Pressure effects on enzyme structure and function in vitro and under simulated in vivo conditions. Comp. Biochem. Physiol. 52 B: 67-74

Menzies, R. J., George, R. Y., Rowe, G. T (1973). Abyssal environment and ecology of the world oceans. John Wiley and Sons, New York

Monniot, C. (1979). Adaptations of benthic filtering animals to the scarcity of suspended particles in deep water. Ambio Spec. Rep. 6: 73-74

Murphy, L. S., Rowe, G. T., Haedrich, R. L. (1976). Genetic variability in deep-sea Echinoderms. Deep Sea Res. 23: 339- -348

Nevo, E. (1978). Genetic variation in natural populations: patterns and theory. Theor. Populat. Biol. 13: 121-177

Rex, M. A. (1981). Community structure in the deep-sea benthos. A. Rev. Ecol. Syst. 12: 331-353

Rokop, F. J. (1974). Reproductive patterns in the deep-sea benthos. Science, N.Y. 186: 743-745

Sanders, H. L. (1969). Benthic marine diversity and the stability time hypothesis. Brookhaven Symp. Biol. 22: 71-80

Sanders, H. L., Grassle, J. F. (1971). The interactions of diversity, distribution and mode of reproduction among major groupings of the deep-sea benthos. In: The world ocean. Proc. Joint Oceanogr. Assembly, Uda, Mled, Japan Soc. Promotion Sci., Tokyo, p. 260-262

Selander, R. K., Smith, M. G., Yang, S. Y., Johnson, W. E., Gentry, J. B. (1971). Biochemical polymorphisms and systematics in the genus Peromyscus. I. Variation in the oldfield mouse (Peromyscus polionotus). Studies in genetics VI. Univ. Texas Publ. 7103: 49-90

Sibuet, M. (1977), Répartition et diversité des échinodermes en zone profonde dans le Golfe de Gascogne. Deep Sea Res. 24: 549-563

Sibuet, M. (1980). Adaptation des échinodermes à la vie abyssale. Proc. European Colloquium on Echinoderms
Brussels. In: Jangoux M. (ed.) Echinoderms: present and past. Balkema Press, Rotterdam, p. 233-240

Sibuet, M., Lawrence, J. M. (1981). Organic content and biomass of abyssal Holothuroids (Echinodermata) from the Bay of Biscay. Mar. Biol. 65: 143-147

Sibuet, M., Khripounoff, A., Deming, J., Colwell, R., Dinet, A (1982). Modification of the gut contents in the digestive tract of abyssal Holothurians. In: Lawrence, J. M. (ed.) Echinoderms. Proc. Inter. Conf. Tampa. Balkema Press Rotterdam, p. 421-428

Siebenaller, J. F. (1978). Gentic variability in deep-sea fishes of the genus Sebastolobus (Scorpaenidae). In: Battaglia B., Beardmore, J. A. (ed.) Marine organisms. Genetics, ecology and evolution. Plenum Press, New York, p. $95-122$

Siebenaller, J. F., Somero, G. N. (1978). Pressure adaptive differences in lactate dehydrogenases of congeneric fishes living at different depths. Science, N.Y. 201: 255-257

Somero, G. N. (1979). Interacting effects of temperature and pressure on enzyme function and evolution in marine organisms. Biochem. biophys. Perspect. mar. Biol. 4: 1-27

Somero, G. N., Hochachka, P. W. (1976a). Biochemical adaptations to pressure. In: Newell, R. C. (ed.) Adaptation to environment: essays on the physiology of marine animals. Butterworths, London, p. 480-510

Somero, G. N., Hochachka, P. W. (1976b). Biochemical adaptations to temperature. In: Newell, R. C. (ed.) Adaptation to environment: essays on the physiology of marine animals. Butterworths, London, p. 125-190

Tyler, P. A., Gage, Y. D. (1979). Reproductive ecology of deepsea Ophiuroids from the Rockall trough. In: Naylor E., Hartnoll R. G. (ed.) Cyclic phenomena in marine plants and animals. Pergamon Press, Oxford, p. 215-222

Valentine, J. W., Ayala, F. J. (1975). Genetic variation in Freileia halli a deep-sea Brachiopod. Deep Sea Res. 22: $37-44$

Valentine, J. W., Ayala, F. J. (1978). Adaptive strategies in the sea. In: Battaglia B., Beardmore, J. A. (ed.) Marine organisms. Genetics, ecology and evolution. Plenum Press, New York, p. 323-345 